\title{
The Explanation of Life Experience Reflection as Ideas of Artistic Research
}

\author{
Hery Budiawan ${ }^{1,3}$; Yusup Sigit Martyastiadi ${ }^{2,3}$ \\ ${ }^{1}$ Music Education, Faculty of Language and Arts, State University of Jakarta; \\ ${ }^{2}$ Interaction Design, Faculty of Art \& Design, Universitas Multimedia Nusantara; \\ ${ }^{3}$ Doctoral Student of Graduate School, Indonesia Institute of the Arts Yogyakarta \\ E-mail: herybudiawan@unj.ac.id; yusup.martyastiadi@umn.ac.id
}

\begin{abstract}
In Indonesia's artistic research, especially for art creation research, many art creative ideas are born from personal experience; however, the artists' subjectivity often constrains them in expressing these experiences. This condition triggers a lack of scientific publications relating to explaining life experiences that underlie creating artwork. This article describes the process of explaining the life experience reflection into the idea of creating artworks. This method is needed to explain emotional triggers into objective knowledge as a scientific research manuscript. This artistic research employs a practice-led research approach. The analysis and discussion are carried out through reflection between ideas of creation, artworks, reviews of existing artworks, and related literature. Researchers convince that the practice-led research methodology is very strategic to boost the quality of writing artistic articles, dissemination, and presentation of arts. Also, this methodology is expected to overcome the gap between art creation and scientific publications. This study offers steps to uncover subjective experiences into objective research. This artistic research can be used to conquer the subjectivity in art creation and the imbalance between scientific publications and the writing of art creation practices.
\end{abstract}

Keywords: artistic research, practice-led research, life experience reflection, art creation

\section{Penjelasan Refleksi Pengalaman Hidup sebagai Gagasan Penelitian Artistik ABSTRAK}

Dalam penelitian artistik di Indonesia, khususnya untuk penelitian penciptaan seni; banyak ide penciptaan seni yang lahir dari pengalaman pribadi, namun mereka sering terkendala oleh subjektivitas seniman dalam mengekspresikan pengalaman ini. Hal ini memicu kurangnya publikasi ilmiah yang berkaitan dengan penjelasan pengalaman hidup yang mendasari gagasan penciptaan karya seni. Artikel ini menjabarkan proses penjelasan refleksi pengalaman hidup ke dalam gagasan penciptaan karya seni. Metode ini diperlukan untuk menjelaskan hal yang subjektif ke dalam pengetahuan yang lebih objektif sebagai naskah penelitian ilmiah. Penelitian artistik ini menggunakan pendekatan penelitian yang didorong oleh praktik (PLR). Analisis dan diskusi dilakukan melalui refleksi antara ide-ide penciptaan, karya seni, ulasan karya seni yang ada, dan literatur terkait. Para peneliti yakin bahwa metodologi penelitian yang didorong oleh praktik sangat tepat guna dalam meningkatkan kualitas penulisan artikel, publikasi dan penyajian seni. Selain itu, metodologi ini diharapkan dapat mengatasi kesenjangan antara praktik penciptaan seni dan publikasi ilmiah. Penelitian ini menawarkan langkah-langkah untuk mengungkap pengalaman subjektif ke dalam penelitian ilmiah yang objektif. Penelitian artistik ini dapat digunakan untuk menjembatani antara subjektivitas dalam penciptaan seni dan ketidakseimbangan antara publikasi ilmiah dan penulisan praktik penciptaan seni.

Kata kunci: penelitian artistik, penelitian yang didorong oleh praktik, refleksi pengalaman hidup, penciptaan seni 


\section{INTRODUCTION}

It is realized that artists and art practitioners cannot be separated from the activities, work, and creative processes that are carried out and the artwork produced. The experience of work and artwork produced by artists and art practitioners is obtained through creative work and artwork. The process of creativity is a research process, and artwork is the research results; it means both are processes and research results. It is misperception when the artists and art practitioners cannot research their art creation experience and artwork. Through the creative process and artworks, artists and art practitioners can find new experiences, methodology, and up to date knowledge.

Artists and art practitioners indirectly have done scientific work in their artistic practice, whether consciously or not. The method can be to do research first by studying existing works and researching experiences with various artist-style interviews. Another method is to conduct direct experiments for the artwork that will be made. This artist's scientific work process has not been written down in scientific writings on a theoretical basis.

The potential to bring art practice to scientific publication still seems to be a discourse because of a gap between artistic publication and scientific publication. Schön (1983), Polanyi (1958), and Cross (2001) believe that this 'logical gap' needs to be accommodated through the art creation methodology in the creative process. What is needed to bridge this logical gap is a credible and competent practitioner's ability to provide confidence in analyzing and explaining the artist and designer (Cross, 2001; Polanyi, 1958; Rust, 2004; Schön, 1983).

On the one hand, artists and art practitioners are occasionally reluctant to write down their creation process in a document because they feel that the artwork itself is sufficient to be submitted to the public and scientific material. Meanwhile, in general, the world of scientific research has not accepted creative work as a single element in the assessment and equivalence of artwork. As long as these artistic publications have not been written textually as literature and reviews, this gap tends to exist. Even though, internationally, the recognition that art practice is equivalent to scientific research has been summarized in recent studies and literature (Barrett \& Bolt, 2007; Gray, 1996; Marley, 2012; Smith \& Dean, 2009; Sullivan, 2006, 2010). As in policies from the Indonesia Ministry of Research, Technology and Higher Education in 2009 and 2014.

To eliminate this gap, it is necessary to think of a method as a balance between practice and scientific writing. Usually, in the process of personal reflection and critical reflection, which is one of the crucial elements of practiceled research, there is a risk of overusing the word "I" and using one's experience as the primary reference for conducting research justification. McNamara (2012) suggests that avoiding this tendency should focus on contributing to knowledge 
IJCAS | Volume 7 Number 2, December 2020

p-ISSN 2339-191X | e-ISSN 2406-9760

even though practice departs from oneself first. Art research now tends to be encouraged to become an interdisciplinary science in order to be more objective. This interdisciplinary knowledge allows researchers to reposition and rearrange art practices related to space and time as a synthesis form. This new understanding is developed in the artist's internal area (which can be called one's 'home' territory) to create a productive 'methodological synthesis' (Kincheloe, 2001).

This article offers the idea that experiences can be used as an idea of art creation to become artwork as an objective and scientific manuscript. The practiceled research approach can bridge the imbalance of art practice with scientific publications in Indonesia. The need for academic accountability, dissemination, and publication for artists, practitioners, academics, and students can be answered by implementing strategic practice-led research to base and frame art practices in Indonesia, especially overcoming artistic research's subjectivity and imbalance between scientific publications and art creation.

\section{METHOD}

The method used in this paper is artistic research through a practice-led research approach, which will be analyzed through reflection between artworks and ideas of creation. The authors see that the practice-led research methodology is very strategic to help improve the quality, dissemination, publication of art creation and address the gap between the practice of artistic creation and scientific publications. Another misconception that often occurs in Indonesia that art creation is instrumental. It means that the concept is described first and the subject matter, practice following the conceptual framework, and research is more dominant in subject matter exploration.

The art practice is only a tool or process to fulfill goals and concepts, which may be premature because it does not experience an iterative exploration of ideaspractices through practice-led research. Even though researchers who employ practice-led research claim that they are creating artwork for the benefit of the audience, in reality, they are making creative work and preparatory work for themselves. In this case, Stock (2010) considers that artists in the art industry are outcome-driven (controlled by results), while artists with a practice-led research approach are more controlled by the process while both are involved in the creative process of creating. The researchers express their personal experiences and serve as creative ideas requiring several stages, depending on the research area and its topic. There are no final stages, like other research approaches. The stage here is more on the researchers' need to execute ideas into artwork in a thoughtful way. Kenna (2012) investigates that this research-led focuses on the principles of art and methods needed by artists to face art challenges through developing experimental 
work methodologies and providing practical examples for methodological testing and demonstrating the findings of this practical research. So, this research contributes to the developing definition of artwork to help artists in their work.

\section{Experience as A Scientific Idea of Creation}

Experience with sound in the past makes it an idea of creation that will be turned into an artwork, on the conceptual work that will become this research. The researcher sees that a timbre point of view based on a sound experience. The experience of a sound becomes a timbre. It means timbre can remember an experience for those who listen to it. Timbre is not just a matter of music, but timbre becomes an association for those who listen to it; so that it can be interpreted as a "sense of sound" for the time being by researchers. Sound has a taste like food, but the taste cannot be absolute because it is subjective. To objectify very subjective things, it takes supporting literature and logic of thinking as a means of making sense. The experience of a person's timbre varies between humans, and it will not be the same when hearing something and feeling it, or in reverse, it feels something and sounds it.

From various literature regarding timbre, there is nothing written about how to see the timbre of the one who made the composition or who listened to it, what was felt, how the emotions occurred after hearing it; timbre is exciting to talk about after listening to it. There are so many differences that will occur and felt because the timbre nature is not well established. It will not even be as established as other things (tone, pitch, duration, strength). The things mentioned are very measurable, so how do you measure the "sense of sound" (mentioned as timbre)? From exploring experiences related to the researcher's emotional "feeling", it is necessary to do research that involves feel and timbre. Experience can make a sound, and sound can be an experience itself. For this reason, there is an in-depth timbre exploration for the need for sound nostalgia to be revealed.

One opinion is that timbre is a complex dimension in the perception of human hearing. The American National Standards Institute (as cited by Reid, 2013) calls timbre an "auditory sensation attribute". In this case, we can judge two sounds with the same loudness and the same pitch with the same loudness in the event of sound. However, pitch and loudness are too simple to describe a timbre phenomenon (Rossing as quoted by Reid, 2013).

The authors see a lack of discourse in reflecting a sound experience into a musical composition with the primary material being timbre, which can be termed from "taste to sound or from sound to taste, vice versa." Consequently, it is deemed necessary for abstraction to bridge between experience, timbre, and music. Timbre has an essential position in composition work to connect and give nostalgic meaning to sound, timbre, and musical composition. Timbre is not only about the 
technicalities, sounds, and instruments in music, but far from it. Timbre is an element that is still relevant as a medium of expression for composers amid limitations in interpreting the true timbre.

Svetlana Boym presents an interesting perspective in his book entitled "The Future of Nostalgia". Boym (2001) defines nostalgia as a longing for a home that does not exist or does not even exist. She categorizes nostalgia into two classes, namely restorative nostalgia and reflective nostalgia. The restorative type is nostalgia as a human effort to revive the past in the present. Reflective nostalgia is a kind of mental recreation of past experiences. Reflective nostalgia will bring in the form of aesthetic pleasure, a blissful journey across the realm of memory without feeling anxious that it will never come back again. Martyastiadi (2020) adds that inconvenience of the past experiences is also encouraging researchers to create perceptions to present new sensations of experience in their artworks. The process of reflection sometimes needs to think logically and structurally. This proves that the idea of experience is very much in line with a very scientific, reflective theory of nostalgia.

After searching through the various literature regarding timbre, timbre memory, nostalgia, emotions, and related musical works, several things that have not been explored can be drawn to reveal the timbre that has been limited to music, physics, and musical instruments. The ongoing debate regarding timbre proves that timbre can indeed be seen from various perspectives. In contrast to pitch, frequency tones are already established by definition because they are absolute. It is this conceptual work that will be important in this artistic research. Researchers see the timbre point of view based on a sound experience. How does the experience of sound become a timbre? or can timbre activate an experience for those who listen to it? Timbre is not just a matter of music, but far from it, timbre as a self-association for those who listen to it can be interpreted as a "sense of sound" for now by researchers. Sound has a taste like food, but the taste cannot be absolute because it is subjective.

\section{Practice-Led Research as A Solution Approach to Experience}

The concept above is an effort to place subjective matters into an objective thing with a practice-led research approach. At least the nature of "me" will be commonplace and not naive in scientific research. The use of the word "I" may occur a lot in creation research with a practice-led research approach. This approach's initially subjective experience became interesting and scientific because every scarcity would reflect some disbursement of data or an interview in nature. This experience provides a new perspective on the world of research and provides a differentiated way of seeing things from various perspectives. 


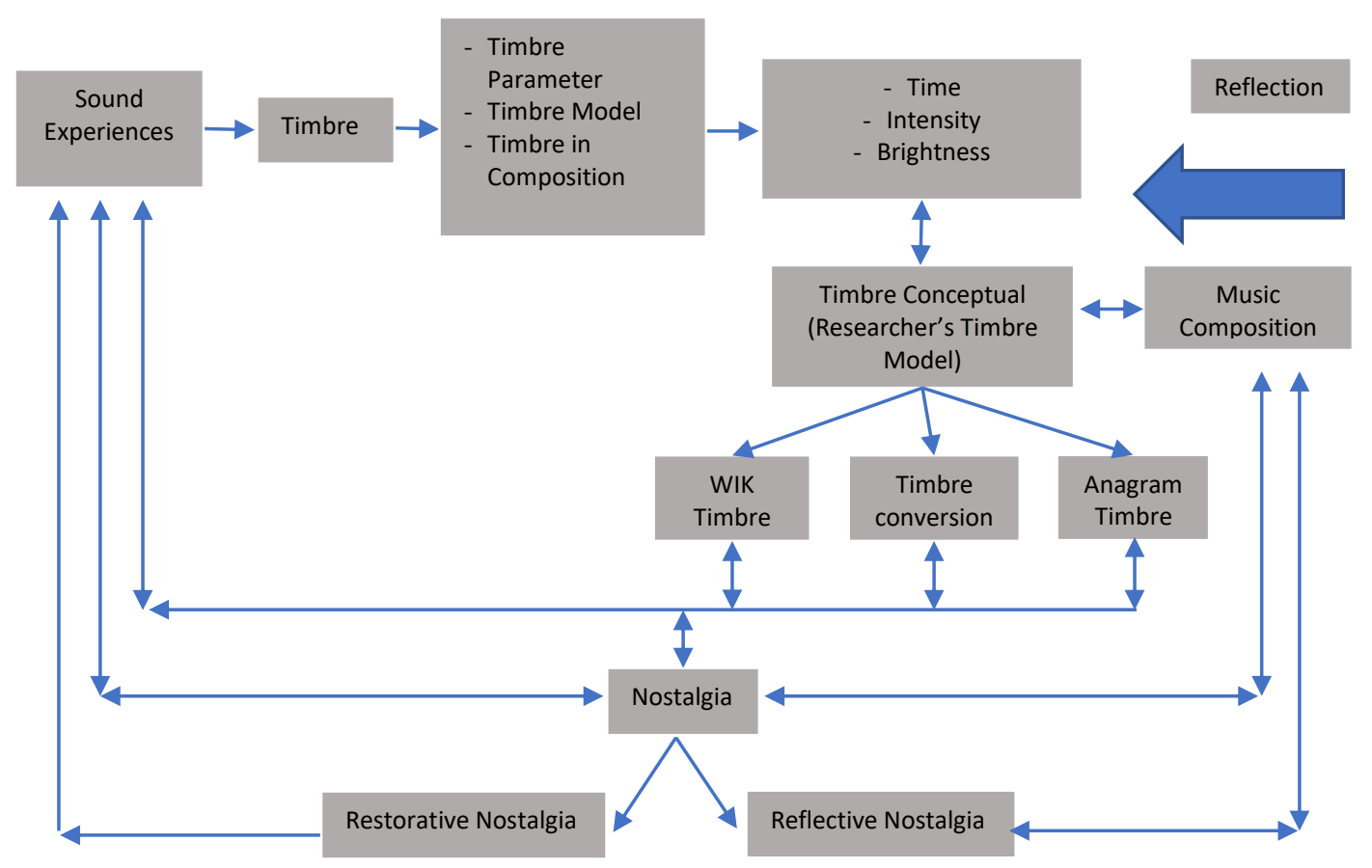

Figure 1. Art Creation Research Framework of "Timbre"

When artists and art academics explore their ability to be responsible for their work, these artists have approached them from an academic perspective (Biggs \& Karlsson, 2011). Kjørup (2010) underlines that artistic research occurs when an artist creates artwork and examines the creative process, then adds the accumulated knowledge of the work and research. Honesty in artists' practice and process in preparing, incubating ideas, implementing and testing theory through practice, conducting experiments through a series of experiments, going into the field, and documenting are essential aspects of research.

Gray (1996) is one of the founders of the principles and definitions of practice-led research, which provides the following explanation:

- research initiated into practice in which questions, problems, challenges are identified and shaped from the needs of the practice and the practitioner.

- research strategies are conveyed through practice, using a predominance of methodologies and specific methods known to practitioners.

Besides, Sullivan $(2006,2010)$ exposed various inquiries related to the debate that art practice can be equated with scientific research.

Practice-led research has become part of the recent development of artistic research. In a practice-led research process, researchers explore the ways in which information can be processed into artworks and textual snippets. The process is circular and spiral; reading and information influence artwork and textual as well as the choice of content to write by the artist/designer (Berridge, 2007). This will 
IJCAS | Volume 7 Number 2, December 2020

p-ISSN 2339-191X | e-ISSN 2406-9760

affect the direction of reading and gathering information so that further dialogue will be created through the relationship between theory and practice. This study emphasizes the relationship between the nature of practice and research results that encourage new knowledge that has operational significance for practice (Candy, 2006).

The practice-led research grew because of the difficulty of art practitioners when using conventional research paradigms. Creative practitioners in the arts and design environment then choose to develop their own research strategies that are more in line with actual practical conditions (Haseman, 2007). Haseman adds that the significance of practice-led research is its potential to initiate and fight for research through art practice. The traditional research approach requires sympathy for the studies they have undertaken, among others by implementing action research, contemporary auto-ethnography, and case studies, which are then framed with postmodern paradigms, feminism, hermeneutics, phenomenology and so on (Stock, 2010).

\section{CONCLUSION}

Through the research that has been carried out, the authors see that the practice-led research methodology is very strategic to help improve quality, dissemination and publication of art creation in Indonesia, and overcoming gaps in art creation practices and academic publications. The following recommendations are made to improve the quality of art creation as research. The first recommendation is to explain works that are easily understood by the general public so that academic publications of art are no longer exclusive but inclusive. The second recommendation is to make it a habit to record each method, new knowledge acquired during the creation process and practice. Third, it is necessary to build cooperation between academics, artists, and art practitioners to review scientific manuscripts resulting from creation research. According to Indonesia's conditions, this joint meeting can discuss practice-led research to reduce the gap between artistic practice and scientific writing.

\section{REFERENCES}

Barrett, E., \& Bolt, B. (Eds.). (2007). Practice as research: Approaches to creative arts inquiry. IB Tauris \& Co Ltd.

Berridge, S. (2007). Arts-based Research and the Creative Ph.D. Proceedings of the 12th Conference of the Australian Association of Writing Programmes.

Biggs, M., \& Karlsson, H. (2011). Evaluating Quality in Artistic Research. In The Routledge Companion to Research in the Arts (pp. 405 - 424). Routledge Taylor and Francis Group. 
Boym, S. (2001). The Future of Nostalgia. Basic Books.

Candy, L. (2006). Practice-Based Research: A Guide. In CCS report 1.

Cross, N. (2001). Designerly Ways of Knowing: Design Discipline Versus Design Science. Design Issue, 17(3).

Gray, C. (1996). Inquiry through practice: developing appropriate research strategies. No Guru, No Method?, 1-28.

Haseman, B. C. (2007). Tightrope writing: Creative writing programs in the RQF environment. TEXT: Journal of Writing and Writing Courses, 11(1), 1-15.

Kenna, H. (2012). A Practice-led Study of Design Principles for Screen Typography with reference to the teachings of Emil Ruder. University of the Arts London, London.

Kincheloe, J. (2001). Describing the bricolage: Conceptualizing a new rigour in qualitative research. Qualitative Inquiry, 7(6), 679- 692.

Kjørup, S. (2010). Pleading for plurality: Artistic and other kinds of research.

Marley, I. . (2012). Investigating the appropriateness of the theory of organizational knowledge creation as a management model for practice-led research. Literator, 33(1), 1-10.

Martyastiadi, Y. S. (2020). From Spiritual to Virtual: An Interactive Digital Art Creation of Virtual Reality Borobudur. Proceedings - NICOGRAPH International 2020, NicoInt 2020, 18-25. https://doi.org/10.1109/NicoInt50878.2020.00011

McNamara, A. E. (2012). Six rules for practice-led research. Text: Journal of Writing and Writing Courses, 14, 1-15.

Polanyi, M. (1958). The Personal Knowledge - Towards a Post-Critical Philosophy. Routledge \& Kegan Paul.

Reid, L. C. (2013). Composing Timbre Spaces, Composing Timbre in Space: An Exploration of the Possibilities of Multidimensional Timbre Representations and Their Compositional Applications. Stanford University.

Rust, C. (2004). Design Enquiry: Tacit Knowledge and Invention in Science. Design Issue, 20(4).

Schön, D. (1983). The Reflective Practitioner - How Professionals Think In Action. Basic Books.

Smith, H., \& Dean, R. T. (2009). Introduction: practice-led research, research-led practice-towards the iterative cyclic web. Practice-Led Research, ResearchLed Practice in the Creative Arts, 1-38.

Stock, C. F. (2010). Aesthetic tensions: evaluating outcomes for practice-led research and industry. TEXT Journal, Special Issue 8.

Sullivan, G. (2006). Research acts in art practice. Studies in Art Education, 48(1), 19-35.

Sullivan, G. (Ed.). (2010). Art practice as research: Inquiry in visual arts. Sage Publications Inc. 